\title{
A review on adsorption heat pump: Problems and solutions
}

\author{
Hasan Demir ${ }^{\mathrm{a}}$, Moghtada Mobedi ${ }^{\mathrm{b}, *}$, Semra Ülkü ${ }^{\mathrm{a}}$ \\ ${ }^{a}$ Department of Chemical Engineering, Izmir Institute of Technology, Gulbahce Campus, 35430 Izmir, Turkey \\ ${ }^{\mathrm{b}}$ Department of Mechanical Engineering, Izmir Institute of Technology, Gulbahce Campus, 35430 Izmir, Turkey
}

Received 14 April 2007; accepted 20 June 2007

\begin{abstract}
Adsorption heat pumps have considerably sparked attentions in recent years. The present paper covers the working principle of adsorption heat pumps, recent studies on advanced cycles, developments in adsorbent-adsorbate pairs and design of adsorbent beds. The adsorbent-adsorbate pair features for in order to be employed in the adsorption heat pumps are described. The adsorption heat pumps are compared with the vapor compression and absorption heat pumps. The problems and troubles of adsorption heat pumps are classified and researches to overcome the difficulties are discussed.
\end{abstract}

(C) 2007 Elsevier Ltd. All rights reserved.

Keywords: Adsorption heat pump; Renewable; Zeolite

\section{Contents}

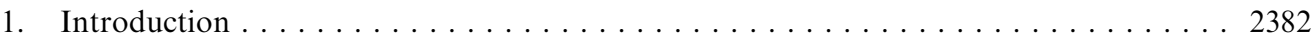

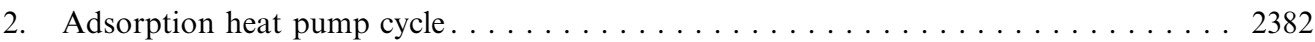

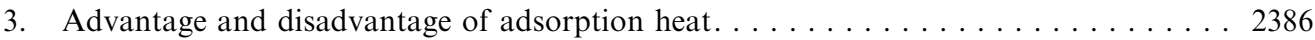

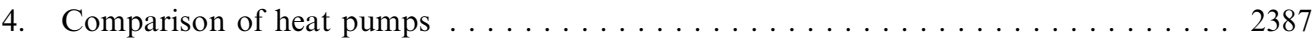

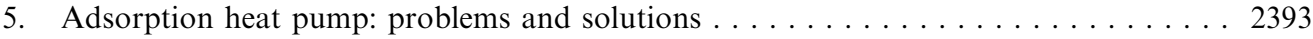

5.1. Advanced adsorption heat pump cycles. . . . . . . . . . . . . . . . . 2394

5.1.1. Uniform temperature adsorber process . . . . . . . . . . . . . . . . . . 2394

${ }^{*}$ Corresponding author. Tel.: + 902327507803 ; fax: + 902327506505 .

E-mail address: moghtadamobedi@iyte.edu.tr (M. Mobedi). 
5.1.2. Thermal wave process . . . . . . . . . . . . . . . . . . 2395

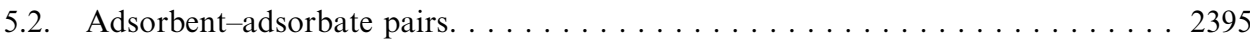

5.3. Adsorbent bed design . . . . . . . . . . . . . . . . . . . . . . . . . 2397

5.3.1. Uncoated type adsorber . . . . . . . . . . . . . . . . . . . . 2398

5.3.2. Coating type adsorber. . . . . . . . . . . . . . . . . . . . . . 2399

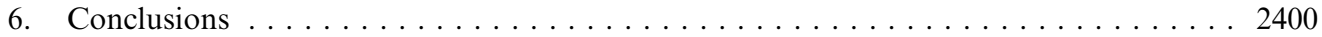

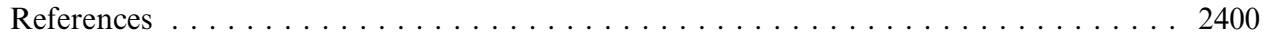

\section{Introduction}

Heating and cooling systems are widely used in industrial and comfort applications. Nowadays, the share of the energy for heating and cooling purposes in total energy consumption increases. Due to the economical benefits resulting from high coefficient of performance (COP) values, mechanical heat pump systems become convenient devices for heating and cooling purposes $[1,2]$. However, in the past two decades, it is found out that the mechanical heat pumps and traditional refrigeration systems play an important role in the depletion of the ozone layer and global warming.

For the protection of the ozone layer, refrigeration technology should continue developing refrigeration systems without ecological damages. Chlorofluorocarbons and hydrochlorofluorocarbons have been prohibited for the protection of ozone layer considering new environmental regulations, which have been accepted first in Montreal in 1988 and in Kyoto in 1998. According to the new regulations, the conventional vapor compression systems are currently worked by using hydrofluorocarbons as refrigerant. However, the use of these new refrigerants has also been restricted due to limitation of the emission of some greenhouse gases $\left(\mathrm{CO}_{2}, \mathrm{CH}_{4}, \mathrm{~N}_{2} \mathrm{O}\right.$, hydrofluorocarbons, PFC, and $\left.\mathrm{SF}_{6}\right)$ in Kyoto protocol. The greenhouse gases might be banned in the next decades [3,4].

Due to the limitation of conventional energy sources, beside the definition of traditional efficiency or performance of devices, the primary energy efficiency must also be considered. Since the mechanical heat pumps work by electrical power, the primary energy efficiency of the mechanical heat pumps will be less than their COP. Recent researches on heat pumps are mostly focused on developing more environmental friendly new systems that have high primary energy efficiency and are able to employ various kinds of energies from the solar energy to waste heat. Adsorption heat pumps that have advantage of being environmental friendly, provide heating and cooling effects by employing thermal energy sources such as solar and geothermal energies or waste heat of the industrial processes. Another important advantage of this type of heat pump is the ability of thermal energy storage. In this paper, a key review on adsorption heat pump researches is performed. Brief information about working principle of adsorption heat pump is presented. The advantages and disadvantages of the pump are explained. The difficulties of adsorption heat pump are classified in this paper. The key studies, which have been performed for solution of these difficulties, are also mentioned.

\section{Adsorption heat pump cycle}

A basic adsorption heat pump cycle consists of four main parts: an adsorber, which is a container filled with an adsorbent (such as zeolite, active carbon, silica gel, etc.); 


\section{Nomenclature}

$C_{p} \quad$ specific heat $\left(\mathrm{kJ} / \mathrm{kg}^{\circ} \mathrm{C}\right)$

COP coefficient of performance

$\Delta H_{\mathrm{a}} \quad$ heat of adsorption $(\mathrm{kJ} / \mathrm{kg}$ adsorbate)

$\Delta H_{\mathrm{v}} \quad$ heat of vaporization $(\mathrm{kJ} / \mathrm{kg}$ adsorbate)

$m \quad$ mass of dry adsorbent $(\mathrm{kg})$

$m_{\text {bed }} \quad$ mass of structure of adsorbent bed $(\mathrm{kg})$

$P \quad$ pressure $(\mathrm{kPa})$

$Q \quad$ heat transferred $(\mathrm{kJ})$

$Q_{a b} \quad$ heat of isosteric heating process $(\mathrm{kJ})$

$Q_{b c} \quad$ heat of isobaric desorption process (kJ)

$Q_{c d} \quad$ heat of isosteric cooling process $(\mathrm{kJ})$

$Q_{d a} \quad$ heat of isobaric adsorption process $(\mathrm{kJ})$

SCP specific cooling power $(\mathrm{W} / \mathrm{kg})$

SHP specific heating power $(\mathrm{W} / \mathrm{kg})$

$T \quad$ temperature $(\mathrm{K})$

$X \quad$ mass fraction of adsorbed adsorbate per dry adsorbent (kg adsorbate/kg dry adsorbent)

\section{Greek symbol}

$\tau_{\text {cyc }} \quad$ period of cycle

\section{Subscripts}

$\begin{array}{ll}\text { bed } & \text { adsorbent bed } \\ \mathrm{c} & \text { condenser } \\ \mathrm{e} & \text { evaporator } \\ \mathrm{h} & \text { heating } \\ \mathrm{ref} & \text { cooling } \\ w & \text { adsorbate } \\ z & \text { adsorbent }\end{array}$

a condenser; an evaporator; and an expansion valve. Basically, adsorption heat pump operates by cycling adsorbate between adsorber, condenser, and evaporator [1-3]. In the adsorption heat pump cycle, adsorption phenomena play the same role of mechanical power, so that the working fluid can be circulated in the cycle without any mechanical power. The adsorption heat pump cycle works between three temperatures levels (Fig. 1) whereas a vapor compression cycle works between two temperature levels and needs a mechanical power.

The adsorption heat pump cycle can be considered as two separate cycles. The first cycle is a heat pump in which the working fluid is vaporized in evaporator by taking heat $\left(Q_{\mathrm{L}}\right)$ from the low-level temperature source and releasing $\left(Q_{\mathrm{a}}\right)$ heat to the first intermediate temperature source. This cycle represents adsorption process. The second cycle is a heat 


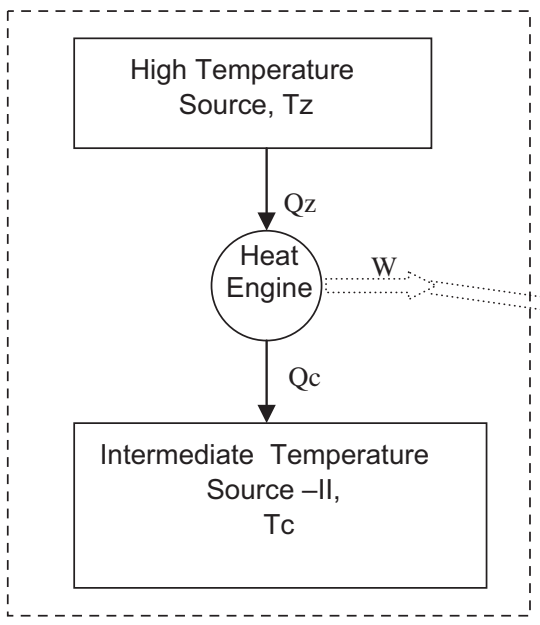

II

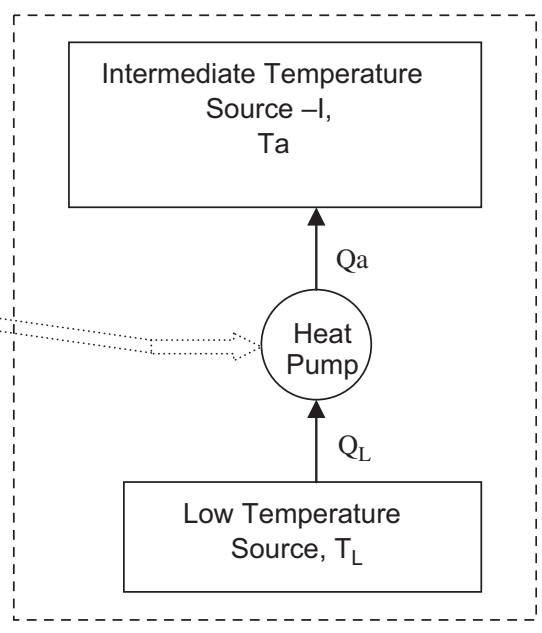

I

Fig. 1. Heat transfer configuration of ideal adsorption heat pump cycle [1].

engine, which receives heat $\left(Q_{\mathrm{z}}\right)$ from the high-temperature source and releases heat $\left(Q_{\mathrm{c}}\right)$ to the second intermediate temperature source. The transfer of heat $\left(Q_{\mathrm{c}}\right)$ to the second intermediate temperature source occurs during the condensation of working fluid in condenser. This cycle represents desorption process. It is assumed that the work obtained in the heat engine is employed to run the heat pump. The temperatures of intermediate sources $\left(T_{\mathrm{c}}\right.$ and $\left.T_{\mathrm{a}}\right)$ are generally close to each other. Thus, three temperature levels can be considered for an adsorption heat pump and the ideal coefficient of performance of an adsorption heat pump cycle can be obtained as [5-7]:

For cooling:

$$
\mathrm{COP}_{\text {ref }}=\frac{Q_{\mathrm{L}}}{Q_{Z}}=\frac{1-\left(T_{C} / T_{Z}\right)}{\left(T_{C} / T_{L}\right)-1} .
$$

For heating:

$$
\mathrm{COP}_{\mathrm{h}}=\frac{Q_{\mathrm{C}}}{Q_{Z}}=1+\frac{1-\left(T_{C} / T_{Z}\right)}{\left(T_{C} / T_{L}\right)-1} .
$$

Fig. 2 illustrates the thermodynamic cycle of a basic adsorption heat pump on an isoster of an adsorbent-adsorbate pair. An isoster of an adsorbent-adsorbate pair indicates the change of the constant amount of adsorbate pressure with respect to temperature. The isosters of the adsorbent-adsorbate pairs are helpful diagrams for determination of thermodynamical cycle of adsorption heat pump and calculation of COP theoretically.

An adsorption heat pump cycle consists of four steps which are isosteric heating $(\mathrm{a}-\mathrm{b})$, isobaric desorption $(b-c)$, isosteric cooling $(c-d)$ and isobaric adsorption $(d-a)$ as shown in Fig. 2.

Isosteric heating $(a-b)$ : The valves between the adsorbent bed and the condenser and evaporator are closed. The temperature of adsorbent bed is increased from $T_{\mathrm{a}}$ to $T_{\mathrm{b}}$ by 

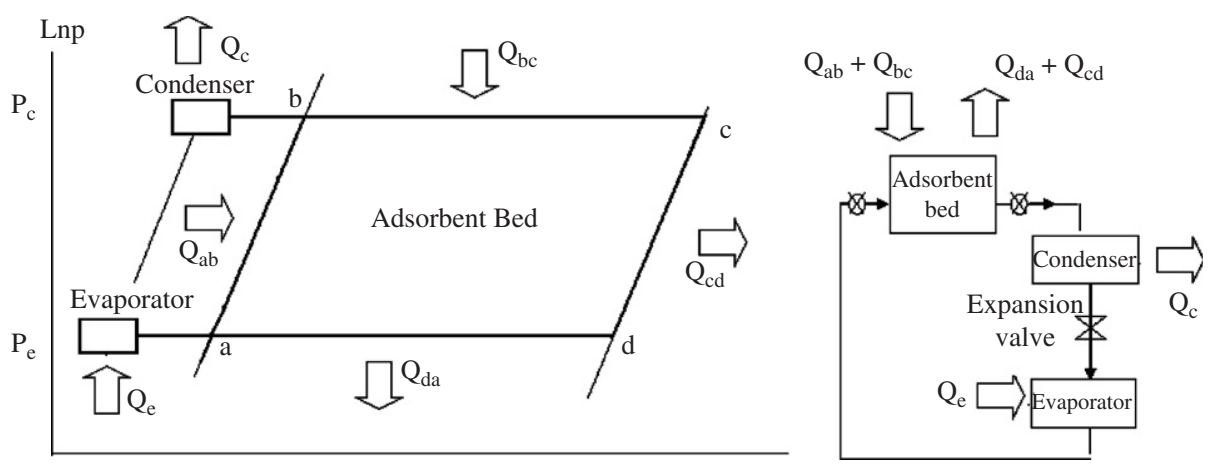

Fig. 2. Thermodynamic cycle of a basic adsorption heat pump.

heating the adsorbent bed without desorption. The amount of heat, which should be transferred to the adsorbent bed to increase temperature of the bed from $T_{\mathrm{a}}$ to $T_{\mathrm{b}}$ is given by the following relation:

$$
Q_{a b}=\int_{T_{\mathrm{a}}}^{T_{\mathrm{b}}}\left[m\left(C_{p, z}+x_{2} C_{p, w}\right)+m_{\mathrm{bed}} C_{p, \text { bed }}\right] \mathrm{d} T .
$$

Isobaric desorption $(b-c)$ : After the isosteric heating of adsorbent bed, the heating process is continued. The valve between the adsorbent bed and condenser is opened. Desorption process is started and water vapor is condensed in the condenser. The pressure of the cycle remains constant. As is seen from Eq. (4), a part of the heat which is transferred to the adsorbent bed increases the temperature of adsorbate-adsorbent pair and adsorbent bed while the other part causes the desorption process:

$$
Q_{b c}=\int_{T_{\mathrm{b}}}^{T_{\mathrm{c}}}\left[m\left(C_{p, z}+x C_{p, w}\right)+m_{\text {bed }} C_{p, \text { bed }}\right] \mathrm{d} T+\int_{b}^{c} m \Delta H_{\mathrm{a}} \mathrm{d} x .
$$

Isosteric cooling $(c-d)$ : The valve between the condenser and adsorbent bed is closed and the temperature of adsorbent bed $\left(T_{\mathrm{c}}\right)$, which is the maximum temperature of the cycle, is decreased to $T_{\mathrm{d}}$. During this process, both the pressure and temperature of the adsorbent bed are decreased to the evaporator values:

$$
Q_{c d}=\int_{T_{\mathrm{c}}}^{T_{\mathrm{d}}}\left[m\left(C_{p, z}+x_{1} C_{p, w}\right)+m_{\mathrm{bed}} C_{p, \text { bed }}\right] \mathrm{d} T .
$$

Isobaric adsorption $(d-a)$ : The valve between the adsorbent bed and evaporator is opened and vaporization of the adsorbate in the evaporator is started. During adsorbing of the adsorbate in the adsorbent, heat is released due to heat of adsorption. This generated heat should be removed from the adsorbent bed and the temperature of adsorbate-adsorbent pair and container should be decreased to $T_{\mathrm{a}}$ :

$$
Q_{d a}=\int_{T_{\mathrm{d}}}^{T_{\mathrm{a}}}\left[m\left(C_{p, z}+x C_{p, w}\right)+m_{\text {bed }} C_{p, \text { bed }}\right] \mathrm{d} T+\int_{d}^{a} m \Delta H_{a} \mathrm{~d} x .
$$


The heat of evaporation, which causes cooling effect and heat of condensation which can be employed for heating purposes, can be determined by the following relation:

$$
\begin{aligned}
& Q_{e}=m \Delta x \Delta H_{\mathrm{v}}+\int_{T_{\mathrm{con}}}^{T_{\mathrm{ev}}} m \Delta x C_{p, w} \mathrm{~d} T, \\
& Q_{c}=m \Delta x \Delta H_{\mathrm{v}} .
\end{aligned}
$$

As it was mentioned, the cooling effect in cycle occurs during the isobaric adsorption process $(\mathrm{d}-\mathrm{a})$ when the adsorbate is evaporated by gaining heat from environment. The heating effect appears during the isobaric desorption process $(b-c)$ when the adsorbate is condensed by releasing heat to surroundings. In addition to the isobaric desorption process, the adsorbent bed is also cooled during $\mathrm{c}-\mathrm{d}$ and $\mathrm{d}-\mathrm{a}$ processes. The heat released during these processes can also be utilized for heating purposes in any process [8]. Hence, the cooling and heating COP of a basic adsorption heat pump can be determined as

$$
\begin{aligned}
& \operatorname{COP}_{\text {ref }}=\frac{Q_{e}}{Q_{a b}+Q_{b c}}, \\
& \operatorname{COP}_{\mathrm{h}}=\frac{Q_{c}+Q_{c d}+Q_{d a}}{Q_{a b}+Q_{b c}} .
\end{aligned}
$$

Specific cooling or heating power (SCP/SHP) value is another expression that describes the effectiveness of the system. The SCP/SHP is the ratio of cooling/heating power per mass of adsorbent per cycle time. In some studies, SCP/SHP is determined according to cooling/ heating power per cycle time and per mass of reactor which consists of mass of adsorbent, mass of heat exchanger in the adsorbent bed, mass of heat transfer fluid (HTF) and mass of container. There are also studies in which SCP/SHP is calculated based on the ratio of reactor volume and cycle time to cooling/heating power. According to the authors, the meaningful definition for SCP/SHP is the ratio of cooling/heating power to the mass of adsorbent and cycle time. The definition of SCP/SHP involves the period of cycle and contributes the comparison of various adsorption heat pump designs [9-11]:

$$
\begin{aligned}
& \mathrm{SCP}=\frac{Q_{e}}{m \tau_{\mathrm{cyc}}}, \\
& \mathrm{SHP}=\frac{Q_{c}+Q_{c d}+Q_{d a}}{m \tau_{\mathrm{cyc}}} .
\end{aligned}
$$

\section{Advantage and disadvantage of adsorption heat}

In recent years, the importance of adsorption heat pumps and adsorption refrigeration systems has increased since these kinds of systems can directly utilize the primary thermal energy sources and additionally the waste heat generated in various industrial processes. The important advantages of the adsorption heat pumps can be described as follows:

- can operate with thermal driving energy sources such as waste heat, solar, and geothermal energies, etc.; 
- can work with low temperature driving energy sources;

- do not require moving parts for circulation of working fluid;

- have long life time;

- operate without noise and vibration;

- have simple principle of working;

- do not require frequent maintenance;

- are environmental friendly since do not contain any hazardous materials for environment; and

- can be employed as thermal energy storage device.

The disadvantages of the adsorption heat pump systems are as follows:

- have low COP values;

- intermittently working principles;

- require high technology and special designs to maintain high vacuum; and

- have large volume and weight relative to traditional mechanical heat pump systems $[3,4,12]$.

\section{Comparison of heat pumps}

The comparison of the adsorption heat pump with the conventional heat pumps which are mechanical and absorption heat pumps contributes understanding of the present position and future of adsorption heat pumps. Table 1 illustrates the comparison of COP values of adsorption heat pump system with absorption and mechanical heat pump systems. The values of COP in this table are obtained based on studies mentioned in Table 2.

As is seen, the COP value of the vapor compression heat pumps is higher than thermal driven pumps with incomparable huge difference. This is the major advantage of the mechanical driven heat pumps; however, thermal driven heat pumps have many other advantages which force industry to employ them. Thermal driven heat pumps operate with waste heat or any kind of thermal energy source. The use of waste heat as a driving energy in adsorption heat pump does not only recover the energy which is thrown away, but also offer a zero operational cost system. The sustainable energy sources such as solar and geothermal energies can be employed in thermal driven heat pumps. This feature is the other advantage for this kind of heat pumps. It should be kept in mind, the vapor

Table 1

Coefficients of performance of heat pump systems for cooling

\begin{tabular}{llc}
\hline Types of heat pumps and working pairs & Coefficient of performance $\left(\mathrm{COP}_{\text {ref }}\right)$ \\
\hline Adsorption & Carbon-methanol & $0.12-1.06$ \\
& Zeolite-water & $0.28-1.4$ \\
& Silica gel-water & $0.25-0.65$ \\
Absorption & Methanol-water & $0.7-1.1$ \\
Vapor compression & Lithium bromide-water & $3-4$ \\
\hline
\end{tabular}


Table 2

Some researched system in literature

\begin{tabular}{|c|c|c|c|c|c|c|c|}
\hline References & $\begin{array}{l}\text { Ref. } \\
\text { no. }\end{array}$ & Adsorbent-adsorbate pair & $\begin{array}{l}\text { Condensation } \\
\text { temperature } \\
\left({ }^{\circ} \mathrm{C}\right)\end{array}$ & $\begin{array}{l}\text { Evaporation } \\
\text { temperature } \\
\left({ }^{\circ} \mathrm{C}\right)\end{array}$ & $\begin{array}{l}\text { Regeneration } \\
\text { temperature } \\
\left({ }^{\circ} \mathrm{C}\right)\end{array}$ & $\mathrm{COP}$ & Remarks \\
\hline Ülkü & [1] & Natural zeolite-water & 53 & 27 & 123 & 0.34 & $\begin{array}{l}\text { Natural zeolite seem as } \\
\text { alternative adsorbent for } \\
\text { adsorption heat pump system. }\end{array}$ \\
\hline Ülkü & [2] & Natural zeolite-water & 52 & 25 & 200 & 0.4 & $\begin{array}{l}\text { Natural zeolite seem as } \\
\text { alternative adsorbent for } \\
\text { adsorption heat pump system. }\end{array}$ \\
\hline Poyelle et al. & [9] & Zeolite-water & 40 & 4 & 230 & 0.74 & $\begin{array}{l}\text { The bed design enhanced mass } \\
\text { and heat transfer rate. }\end{array}$ \\
\hline $\begin{array}{l}\text { Ülkü and } \\
\text { Mobedi }\end{array}$ & [12] & $\begin{array}{l}\text { Carbon-methanol-zeolite-water } \\
\text { carbon-ammonia }\end{array}$ & & & & & $\begin{array}{l}\text { Common used } \\
\text { adsorbent-adsorbate pairs are } \\
\text { investigated. }\end{array}$ \\
\hline $\begin{array}{l}\text { Douss and } \\
\text { Meunier }\end{array}$ & [13] & Zeolite-water-carbon-methanol & 35 & 25 & $\begin{array}{l}220 \text { for zeolite } \\
\text { bed, } 100 \text { for } \\
\text { carbon bed }\end{array}$ & 1.06 & $\begin{array}{l}\text { Heat required during } \\
\text { regeneration of Carbon bed is } \\
\text { provided from zeolite beds. }\end{array}$ \\
\hline $\begin{array}{l}\text { Pons and } \\
\text { Szarzynski }\end{array}$ & [15] & Zeolite-water & 45 & 3 & 290 & & $\begin{array}{l}\text { Influence of physical properties } \\
\text { of heat transfer fluid on AHP } \\
\text { system. }\end{array}$ \\
\hline $\begin{array}{l}\text { Hamamoto } \\
\text { et al. }\end{array}$ & {$[18]$} & Silica gel-water & 30 & 14 & 55 & 0.25 & $\begin{array}{l}\text { Amount of adsorbent is } \\
\text { allocated to adsorbent beds and } \\
\text { effect of mass ratio is } \\
\text { investigated. }\end{array}$ \\
\hline Khan et al. & [20] & Silica gel-water & 30 & 14 & 60 & $0.3-0.65$ & $\begin{array}{l}\text { Effect of silica gel mass on COP } \\
\text { is investigated. }\end{array}$ \\
\hline $\begin{array}{l}\text { Cerkvenik et } \\
\text { al. }\end{array}$ & [23] & Zeolite 13X-LiBr-Water & 27 to 35 & 12 to 6 & 110 & 0.33 & $\begin{array}{l}\text { Zeolite-water adsorption } \\
\text { system is combined LiBr-water } \\
\text { absorption system for } \\
\text { providing continuous system. }\end{array}$ \\
\hline
\end{tabular}


Polyaniline/Zeolite composite is prepared for enhancement of heat transfer of adsorbent bed. Optimum coating thickness is

Restuccia

[26] Zeolite-water

et al.

Hamamoto

AC-methanol

-5 to 35

-20 to +15

40-100

0.38

Senatalar

Meunier

Zeolite-water

Bonarccorsi

Zeolite-water

et al

Riffat et al

Bonarccorsi

and

[33] Zeolite-water

Proverbio

Lambert

[34] Carbon-ammonia

\section{determined.}

Mass transfer is enhanced by using activated carbon fiber.

Compared two bed scheme

with four-bed scheme that

improves the recovery

efficiency by about $70 \%$.

Lighter adsorption heat pump

system can be obtained with

using polymeric heat exchanger tubes.

Exergy analysis of four cascades cycled heat pump systems is performed.

Open cell copper foam is applied on AHP for improving heat transfer properties.

System requires operating pressure about 8 bars for HFC as adsorbate.

Optimization of zeolite coating process on stainless steel tube.

A new configuration provides the higher contact area between adsorbent and heat exchanger. Adsorbent bed generally has heavy weight. Adsorber must be designed lightweight to reduce sensible heat losses from body.

Waste heat of evaporation desallination process is used for cooling purposes by AHP.

Optimum coating thickness is determined. 


\begin{tabular}{|c|c|c|c|c|c|c|c|}
\hline References & $\begin{array}{l}\text { Ref. } \\
\text { no. }\end{array}$ & Adsorbent-adsorbate pair & $\begin{array}{l}\text { Condensation } \\
\text { temperature } \\
\left({ }^{\circ} \mathrm{C}\right)\end{array}$ & $\begin{array}{l}\text { Evaporation } \\
\text { temperature } \\
\left({ }^{\circ} \mathrm{C}\right)\end{array}$ & $\begin{array}{l}\text { Regeneration } \\
\text { temperature } \\
\left({ }^{\circ} \mathrm{C}\right)\end{array}$ & $\mathrm{COP}$ & Remarks \\
\hline $\begin{array}{l}\text { Tatlier and } \\
\text { Şenatalar }\end{array}$ & {$[38]$} & Zeolite-water & 20 & 2 & 151 & & $\begin{array}{l}\text { The effects of thermal and mass } \\
\text { diffusivities on the performance } \\
\text { of AHP is studied. }\end{array}$ \\
\hline $\begin{array}{l}\text { Tatlier and } \\
\text { Şenatalar }\end{array}$ & [39] & Zeolite-water & & & & & $\begin{array}{l}\text { Optimum coating thickness is } \\
\text { determined for zeolite type } \\
(13 \mathrm{X} \text { and } 4 \mathrm{~A}) \text {. }\end{array}$ \\
\hline $\mathrm{Wu}$ et al. & [40] & Carbon-methanol & & 7 & 90 & & $\begin{array}{l}\text { Influence of adsorption and } \\
\text { desorption capacity on } \\
\text { operating process for AHP is } \\
\text { studied. }\end{array}$ \\
\hline $\begin{array}{l}\text { Sakoda and } \\
\text { Suzuki }\end{array}$ & {$[41]$} & Silica gel-water & 35 & 5 & 100 & & $\begin{array}{l}\text { Solar energy driven adsorption } \\
\text { heat pumps are studied. }\end{array}$ \\
\hline $\begin{array}{l}\text { Aittomaki } \\
\text { and } \\
\text { Harkönen }\end{array}$ & {$[42]$} & Zeolite-methanol & 55 & -5 & 155 & 1.34 & $\begin{array}{l}\text { Mini scale (lab) apparatus is } \\
\text { constructed. }\end{array}$ \\
\hline Critoph & [43] & Carbon-water & 42 & 0 & 250 & 0.95 & $\begin{array}{l}\text { Forced convection is used for } \\
\text { improving mass transfer. }\end{array}$ \\
\hline $\begin{array}{l}\text { Lemini and } \\
\text { Meunier }\end{array}$ & [44] & A. carbon-methanol & & & & 0.114 & $\begin{array}{l}\text { Adsorptive solar refrigeration } \\
\text { system is simulated. }\end{array}$ \\
\hline Ramos et al. & {$[45]$} & Zeolite-water & & & & & $\begin{array}{l}\text { Solar energy driven AHP is } \\
\text { designed. }\end{array}$ \\
\hline $\begin{array}{l}\text { Hening and } \\
\text { Glaser }\end{array}$ & [46] & Silica gel-water & & & & 0.6 & $\begin{array}{l}\text { AHP system is applied on air- } \\
\text { conditioning of buildings. }\end{array}$ \\
\hline Sumathy & [47] & A. carbon-methanol & 35 & -10 & 100 & 0.12 & $\begin{array}{l}\text { Solar powered AHP is used for } \\
\text { ice-making. }\end{array}$ \\
\hline $\begin{array}{l}\text { Dechang } \\
\text { et al. }\end{array}$ & {$[48]$} & A. carbon-methanol & & & & & $\begin{array}{l}\text { Dynamic simulation of AHP is } \\
\text { studied. }\end{array}$ \\
\hline $\begin{array}{l}\text { Tatlier and } \\
\text { Șenatalar }\end{array}$ & [49] & Zeolite-water & 20 & 2 & & & $\begin{array}{l}\text { Solar powered AHP is studied } \\
\text { with zeolite coated adsorbent } \\
\text { bed. }\end{array}$ \\
\hline Wu et al. & {$[50]$} & A. carbon-methanol & 27 & -10 & 100 & 0.5 & $\begin{array}{l}\text { Dynamic analysis of heat } \\
\text { recovery process for AHP. }\end{array}$ \\
\hline Tahat & [51] & Silica gel-water & & & & & $\begin{array}{l}\text { Lab scale AHP system is } \\
\text { constructed. }\end{array}$ \\
\hline
\end{tabular}



0

et al

Gross and

Dawoud

Metcalf

De Boer

et al.

Telto

Thorpe et al.

\section{Silica gel-water}

Carbon-ammonia

[61] $\mathrm{CaCl}_{2}+\mathrm{Al}_{2} \mathrm{O}_{3}-$ Ammonia $\mathrm{CaCl}_{2}+$ A. carbon-Ammonia

$\begin{array}{lll}\begin{array}{l}\text { Hamamoto } \\ \text { et al. }\end{array} & {[62]} & \text { Silica gel-water } \\ \text { Hauer } & {[63]} & \text { Silica gel-water Zeolite-water }\end{array}$

$0.6-0.62$

$0.117-0.143$
Effect of metal mass on the performance of AHP.

Solar-hybrid powered AHP system is designed and applied for decentralized cold storage of agricultural products.

AHP system is applied on airconditioning of buildings.

One of the first applications.

New construction is designed and tested for zeolite-water AHP system.

Computer simulation model of an isothermal

carbon-ammonia AHP bed is developed in MATLAB software.

Small capacity AHP is constructed and tested for heating and cooling

applications.

Compact solid sorption heat pump is developed and tested. Experimental test of compact sorption generator prototype.

Ammonia adsorption behavior on new adsorbent composite materials.

Development of hybrid desiccant cooling system combined with 2 stage adsorption chiller.

Comparison of adsorbents (zeolite \& silica gel) due to their energy storage capacity.

Novel adsorption chiller is developed and tested. 


\begin{tabular}{|c|c|c|c|c|c|c|c|}
\hline References & $\begin{array}{l}\text { Ref. } \\
\text { no. }\end{array}$ & Adsorbent-adsorbate pair & $\begin{array}{l}\text { Condensation } \\
\text { temperature } \\
\left({ }^{\circ} \mathrm{C}\right)\end{array}$ & $\begin{array}{l}\text { Evaporation } \\
\text { temperature } \\
\left({ }^{\circ} \mathrm{C}\right)\end{array}$ & $\begin{array}{l}\text { Regeneration } \\
\text { temperature } \\
\left({ }^{\circ} \mathrm{C}\right)\end{array}$ & $\mathrm{COP}$ & Remarks \\
\hline Wang et al. & {$[65]$} & Silica gel-water & 30 & 15 & $60-92$ & 0.4 & $\begin{array}{l}\text { Micro adsorption chiller is } \\
\text { applied on natural gas \& LPG } \\
\text { power cogeneration system. }\end{array}$ \\
\hline $\begin{array}{l}\text { Elgowainy } \\
\text { et al. }\end{array}$ & [66] & A. carbon-ammonia & & & & $\begin{array}{l}\text { Cooling } \\
0.36 \text {, heating } \\
1.1-1.15\end{array}$ & $\begin{array}{l}\text { Two ton solid sorption heat } \\
\text { pump system is built and tested } \\
\text { for cooling and heating } \\
\text { performance evaluations. }\end{array}$ \\
\hline $\begin{array}{l}\text { Restuccia } \\
\text { et al. }\end{array}$ & [67] & SWS-water & 35 & 10 & 90 & $0.17-0.48$ & $\begin{array}{l}\text { Advanced solid sorption chiller } \\
\text { based on coated heat exchanger } \\
\text { with SWS is tested and } \\
\text { achieved a cycle time of } \\
20-40 \mathrm{~min} \text {. }\end{array}$ \\
\hline $\mathrm{Wu}$ et al. & {$[68]$} & Silica gel-water & & & & $0.427-0.434$ & $\begin{array}{l}\text { Effects of variation of heat } \\
\text { source on COP of AHP are } \\
\text { investigated. }\end{array}$ \\
\hline Wang et al. & [69] & $\mathrm{CaCl}_{2}+$ A. carbon-ammonia & & -20 & 135 & 0.36 & $\begin{array}{l}\text { Ice-making system uses heat } \\
\text { pipe principle to perform the } \\
\text { heating and cooling process for } \\
\text { adsorber. }\end{array}$ \\
\hline $\begin{array}{l}\text { Schanbel } \\
\text { and Henning }\end{array}$ & {$[70]$} & & & & 95 & & $\begin{array}{l}\text { Experimental and numerical } \\
\text { simulation of water vapor } \\
\text { adsorption behavior on } \\
\text { different adsorbents. }\end{array}$ \\
\hline $\begin{array}{l}\text { Choi and } \\
\text { Jeong }\end{array}$ & [71] & Silica gel-water & 40 & 25 & 100 & & $\begin{array}{l}\text { Development of micro } \\
\text { refrigeration system. }\end{array}$ \\
\hline Dawoud & [72] & Zeolite-water-SWS-water & 55 & -5 & 122 & 0.28 & $\begin{array}{l}\text { Hybrid adsorption cooling unit } \\
\text { for vaccine storage utilizing } \\
\text { solar energy as main power } \\
\text { supply and a gas burner as an } \\
\text { alternative power supply is } \\
\text { developed and tested. }\end{array}$ \\
\hline
\end{tabular}


compression heat pumps operate with electrical power which is generally produced by the heat of fossil fuels. Thus, the primary energy efficiency of mechanical heat pumps will be less than their COP values due to energy losses occur in power plants and compressors, and during transfer of electrical power.

From the practical application point of view, the major advantage of the adsorption heat pumps is that they do not need maintenance for long periods since they do not contain any moving parts or in advanced systems they have a few simple moving parts. The life time of absorption heat pump is shorter than adsorption one due to problem of salt corrosion. Moreover, the absorbent used in absorption system should be changed every $4-5$ years. In adsorption heat pump, the system does not require changing of the adsorbent-adsorbate pairs for a long period of time. No corrosive chemical materials are employed in adsorption heat pump systems. As it was mentioned before, the vapor compression heat pumps use toxic and greenhouse gases. Some of refrigerants have been banned and others will be prohibited in future. These problems of mechanical heat pumps increase attractions on adsorption heat pump systems and make them comparative even respect to the absorption heat pumps, which are another kind of thermal driven heat pumps.

\section{Adsorption heat pump: problems and solutions}

The application of adsorption heat pumps has their own difficulties and problems. An intermitted principle of working, high technology for working under high vacuum and design of adsorbent bed in which a coupled heat and mass transfer forms are some of these difficulties. The studies on the adsorption heat pumps are focused on developing an adsorption heat pump system, which can technically and economically be a serious alternative to the conventional systems.

The aim of researchers is to develop an adsorption heat pump which

- has continuous cooling or heating process,

- has high COP values,

- can operate with lower temperature driving energy, and

- has practical design for construction and application.

The list of the performed study is shown in Table 2. The employed adsorbent-adsorbate pair, condensation and evaporation temperatures, desorption temperature of the studies are given in the table. The COP values for the studies in which the cycle is theoretically or experimentally achieved are also presented. Some studies have been focused on bed design or solution of heat and mass transfer equations. Thus, no COP value is given for those studies. The aim or result of studies is explained in the remarks column. Thus, the reader can easily follow studies in this table.

Based on a detailed literature survey, the performed studies on the adsorption heat pumps can be categorized into three areas. The studies are performed on

- advanced adsorption cycles in order to increase COP, operate with lower temperature driving heat source and provide continuous cooling or heating process;

- new adsorbent-adsorbate pairs or promoting the existence pairs in order to increase adsorption rate, enhance COP and decrease the temperature of driving heat source; and

- design of an adsorbent bed for appropriate heat and mass transfer. 


\subsection{Advanced adsorption heat pump cycles}

Literature survey has shown that many studies on adsorption heat pump have been performed in order to increase the COP values and provide a continuous cooling or heating process. In the most of papers, the developed systems have been called as advanced adsorption heat pump cycles. The continuity of cooling and heating processes is generally provided by increasing the number of adsorbers. The increase of COP is obtained by recovering and utilizing heat, which is transferred during isosteric cooling $(\mathrm{c}-\mathrm{d})$ and isobaric adsorption ( $\mathrm{d}-\mathrm{a})$ in another adsorption cycle. This increases the COP of cycle since the amount of external heat supplied to the cycle is reduced. The advanced cycles can be categorized into two groups, which are briefly explained in this section $[3,13]$.

\subsubsection{Uniform temperature adsorber process}

These systems consist of two or more adsorbers, operating with the same refrigerant, a single evaporator and a single condenser. A general view of the uniform temperature adsorber cycle is shown in Fig. 3. In this system, one of the adsorbers is preheated with rejection heat of another adsorber which is under the cooling process. The transfer of heat between the adsorbers is performed by a heat transfer fluid. The process continues until both adsorbers reach to the same temperature $(\mathrm{G}$ and $\mathrm{H})$. After this period of heat recovery, one adsorber is heated by the external heat source (GD) while the other one is cooled by the external heat sink (HA) [10]. Although each adsorber follows exactly the same cycle as the basic adsorption heat pump cycle, the heat which is supplied to the total system decreases. This type of advanced cycle results in enhancement of the COP up to 50\% $[3,13,14]$.

Dous and Meunier [13] have proposed and made another alternative adsorption cycle. The proposed adsorption cycle consists of two cycles, a zeolite-water cycle for hightemperature stage and an active carbon-methanol cycle for low-temperature stage. The heat which should be transferred to the active carbon-methanol cycle for isosteric heating and isobaric desorption processes is completely obtained from the zeolite-water cycle. The driving energy for zeolite-water cycle is supplied from an external heat source. The experimental COP for cooling was found as 1.06 .

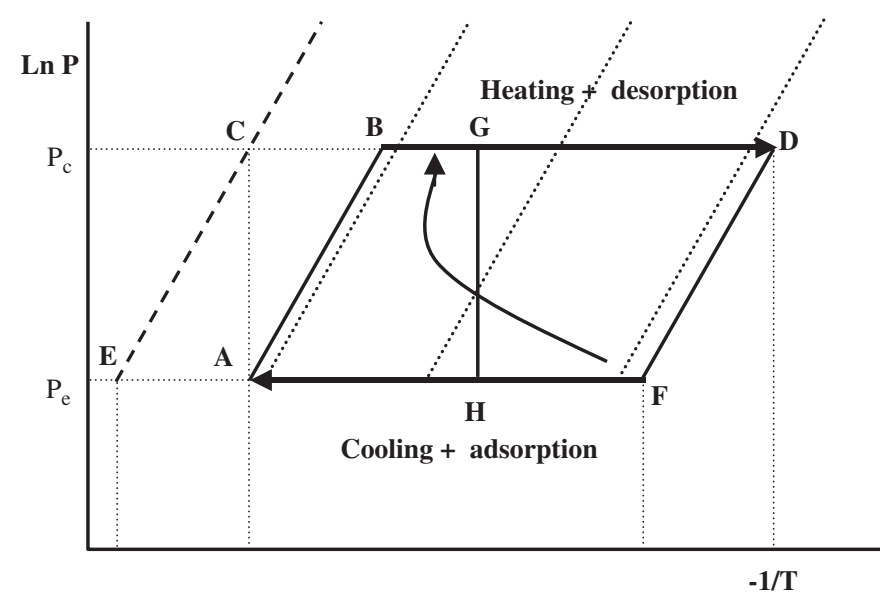

Fig. 3. Working principle of an adsorption cycle with uniform temperature adsorbers [14]. 


\subsubsection{Thermal wave process}

The system is composed of two or more adsorbers, a condenser and an evaporator. The working principle of a thermal wave process is shown in Fig. 4. The cycle consists of two adsorbers which are called as adsorber 1 and 2. A heat transfer fluid is circulated between the two adsorbers. While adsorber 1 is under cooling, the adsorber 2 is under heating process and vice versa. For the case shown in Fig. 4, the heat which is recovered from the adsorbent 1 is transferred to the heat transfer fluid. The heating of fluid is continued to desorption temperature by a heating system and then it is fed to adsorber 2 for the isobaric desorption process. After leaving of heat transfer fluid from adsorber 2, it is cooled by a cooler to be fed into the adsorber 1 . Hence, the heat transfer fluid completes a cycle in the system. A reversible pump is used to change flow direction of heat transfer fluid for the reverse process, when the adsorber 2 is under cooling and adsorber 1 is under heating stage [3,13-16].

As it was mentioned before, many studies which have been performed to increase the COP of the adsorption heat pumps can be found in literature. Among those studies, the system of Saha et al. [17] and Hamamoto et al. [18] is remarkable. They worked on an advanced two stages adsorption heat pump cycle and improved the thermal wave process by employing two additional adsorbers in cycle. They found that the cooling capacity of two stages adsorption heat pump can be improved by allocating required adsorbent mass between adsorbers. The main advantage of the improved two stages adsorption heat pump is being capable to utilize low temperature solar/waste heat $\left(40-95^{\circ} \mathrm{C}\right)$ as driven heat source [17-20].

\subsection{Adsorbent-adsorbate pairs}

The adsorbent-adsorbate pair, which must be compatible with the environment, is one of the important parts of adsorption heat pump system. Main requirements of the adsorbate are high latent heat, non-corrosive, non-toxicity and good thermal and chemical stability within the working conditions (temperature and pressure ranges). On the other hand, adsorbents should have high adsorption capacity, high thermal conductivity, low cost and also thermal stability. Zeolite-water, active carbon-methanol, silica gel-water, and carbon-ammonia are some of the common adsorbent-adsorbate pairs used in adsorption heat pump systems [21-23].

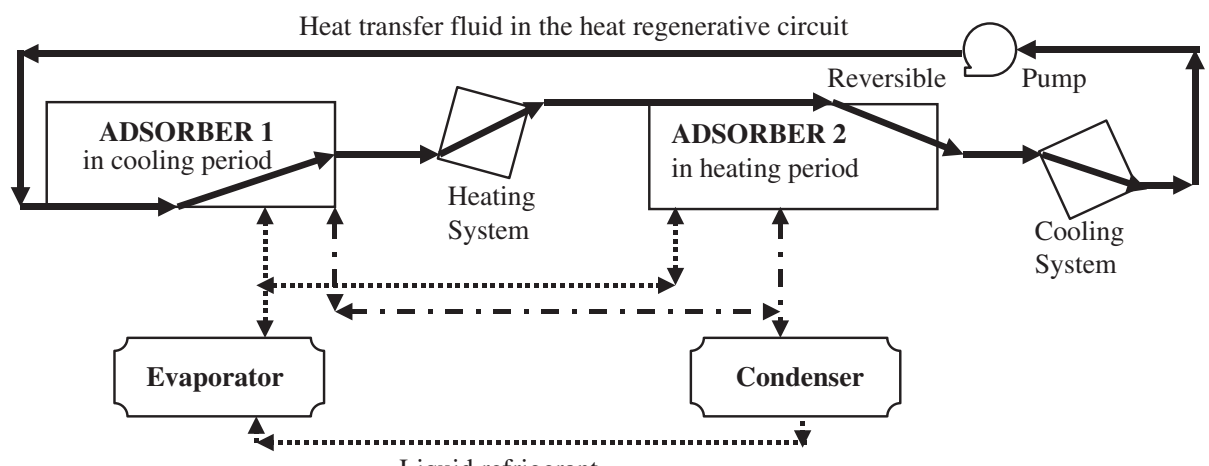

Fig. 4. Working principle of an adsorption heat pump cycle with thermal wave process [15]. 
Another important criterion for the selection of appropriate adsorbent-adsorbate pair is the type of interaction between solid adsorbent and vapor adsorbate. The interaction between adsorbent and adsorbate is called as adsorption. In an adsorption process, adsorbate interacts on solid surface of adsorbent with cohesive forces including van der Waals forces and hydrogen bond. There are two types of adsorption which are called as physical and chemical adsorptions. The physical adsorption or physisorption is caused by van der Waals forces and chemical adsorption or chemisorption involves valence forces. In adsorption heat pumps, the adsorption and desorption processes have to be reversible to provide repetition of the same cycle. Therefore, the interaction between adsorbent and adsorbate must be a physical adsorption type [4,23].

Table 3 illustrates the comparison of adsorbent-adsorbate pairs according to maximum adsorbate capacity, heat of adsorption values, adsorbent specific heat, energy density, and operating temperature range [12]. For the selection of a convenient adsorbent adsorbate pair not only the adsorption capacity, which may seem the most important parameter, but also the other properties such as operating temperature range, reversibility and cost must also be considered.

For many adsorbent-adsorbate pairs, the adsorption heat pump cycle operates under high vacuum. It is difficult to maintain the operation pressure in a high vacuum for a long time. This requires vacuum technology, special materials and gaskets which increase the cost of adsorption heat pump and cause the use of heavier containers. Some studies have been performed to obtain systems that can operate at moderate evaporation or condensation pressure. Wang and Zhu [24] have proposed an innovative

Table 3

Comparisons of adsorbent-adsorbate pairs (Ülkü and Mobedi [12])

\begin{tabular}{|c|c|c|c|c|c|}
\hline Adsorbate-adsorbent & $\begin{array}{l}\text { Maximum } \\
\text { adsorbate } \\
\text { capacity } \\
(\mathrm{kg} / \mathrm{kg})^{\mathrm{a}}\end{array}$ & 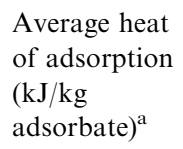 & $\begin{array}{l}\text { Adsorbent } \\
\text { specific heat } \\
(\mathrm{kJ} / \mathrm{kg})^{\mathrm{a}}\end{array}$ & $\begin{array}{l}\text { Energy } \\
\text { density } \\
\text { (kJ/kg } \\
\text { adsorbate) }\end{array}$ & $\begin{array}{l}\text { Temperature } \\
\text { range }\left({ }^{\circ} \mathrm{C}\right)\end{array}$ \\
\hline Water-zeolite 4A & 0.22 & 4400 & 1.05 & 1250 & $30-350$ \\
\hline Water-zeolite 5A & 0.22 & 4180 & 1.05 & 1200 & $30-350$ \\
\hline Water-zeolite MgA & 0.29 & 3400 & 1.06 & 800 & $60-250$ \\
\hline Water-zeolite 13X & 0.30 & 4400 & 0.92 & 1290 & $30-350$ \\
\hline Water-zeolite $13 \mathrm{X}$ & 0.27 & & 0.84 & 930 & $20-300$ \\
\hline Water-zeolite 10A & 0.20 & 4000 & & 897 & $50-250$ \\
\hline Water-zeolite 13X & 0.27 & 3400 & 1.06 & 1200 & $30-350$ \\
\hline Water-clinoptilolite & 0.12 & 3000 & 1.11 & 480 & $20-240$ \\
\hline Water-mordenite & 0.11 & 4000 & & 419 & $30-350$ \\
\hline Water-chabazite & 0.17 & 3000 & 1.08 & 700 & $30-250$ \\
\hline Water-charcoal & 0.40 & 2320 & 1.09 & 1200 & $30-250$ \\
\hline Water-ac. alumina & 0.19 & 2480 & 1.00 & 660 & $30-250$ \\
\hline Water-silica gel & 0.37 & 2560 & 0.88 & 1000 & $30-150$ \\
\hline Water-silica gel & 0.20 & 2500 & 1.045 & 600 & $20-130$ \\
\hline Methanol-zeolite 13X & 0.20 & 2400 & 1.07 & & \\
\hline Methanol-zeolite 4A & 0.16 & 2300 & 1.07 & & \\
\hline Methanol-zeolite 5A & 0.17 & 2300 & 1.07 & & \\
\hline Methanol-zeolite 5A & 0.17 & 2300 & 1.07 & & \\
\hline Methanol-ac. carbon & 0.32 & 1400 & 0.9 & 590 & $20-140$ \\
\hline
\end{tabular}

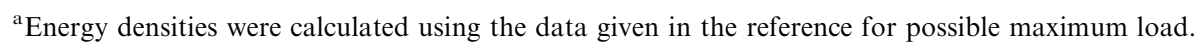



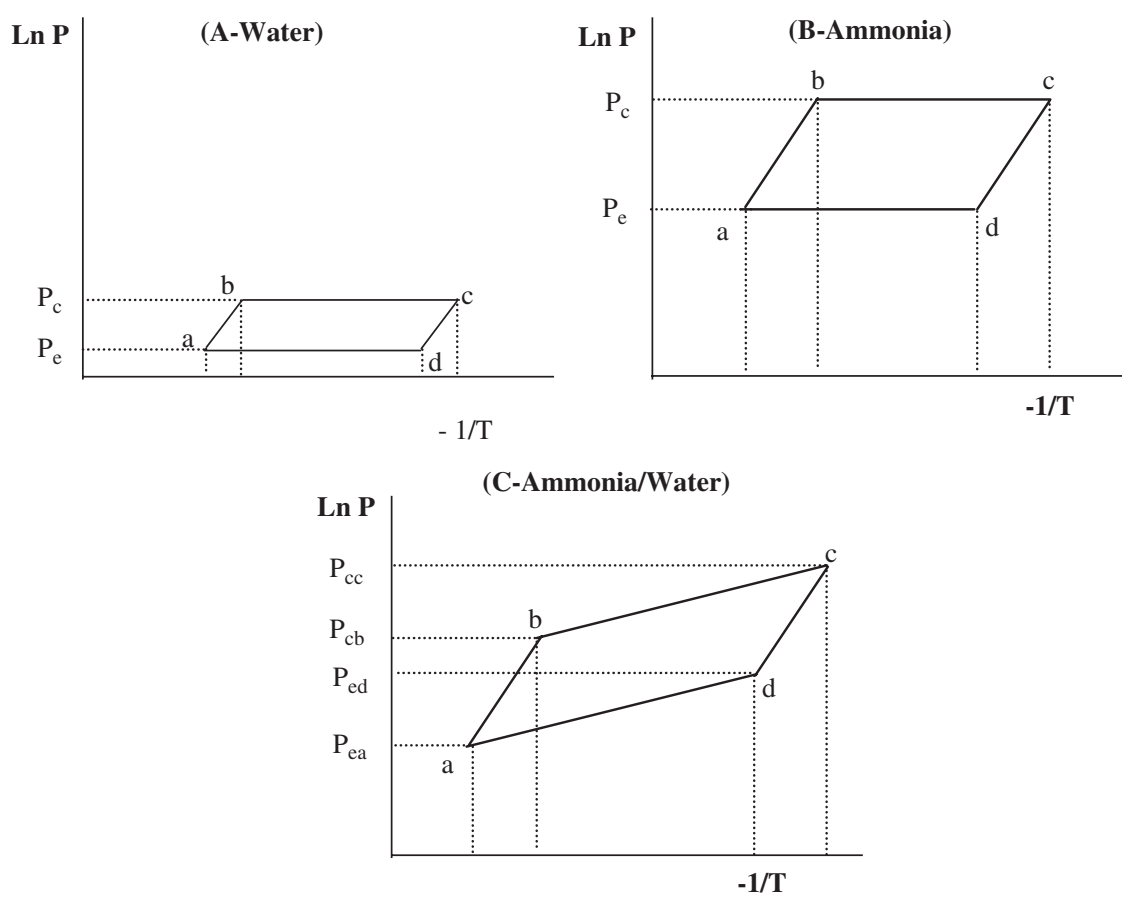

Fig. 5. Ideal cycle of the system on isosteric graphs for single and binary working fluid [24].

adsorption heat pump cycle which operates with binary working fluid $\mathrm{NH}_{3}$ and $\mathrm{H}_{2} \mathrm{O}$. The differences between the cyclic behaviors of the single and binary working fluid systems are shown in Fig. 5. The operation pressure of the water-zeolite system is low and requires high vacuum in the cycle (Fig. 5A), however, the $\mathrm{NH}_{3}$-zeolite cycle operates at higher pressure which is 4-11 times higher than the ambient pressure (Fig. 5B). With an appropriate mixing of ammonia and water, a cycle which operates with a pressure close to ambient pressure can be obtained as shown in Fig. 5C. This improvement may solve one of the problems of the adsorption heat pump which is working under high vacuum [24].

\subsection{Adsorbent bed design}

The design of adsorbent bed is the other difficulty of adsorption heat pumps. Adsorbent bed requires a special design for controlling heat and mass transfer. Theoretical studies have shown the influence of both heat and mass transfer kinetics on performance of adsorption heat pump system [16]. Since thermal conductivity of adsorbents is generally low, heat is transferred slowly through the adsorbent bed as well as the periods of adsorption and desorption processes become longer. The mass transfer depends on adsorbate flow through the bed (interparticle flow) and through the adsorbent (intraparticle diffusion due to concentration differences, molecular diffusion, Knudsen diffusion, and surface diffusion). In order to determine temperature and concentration profiles in the adsorbent bed, heat and mass transfer equations have to be solved for the adsorber. The governing equations for transport of heat and mass are coupled and should 
be solved simultaneously. The results produce important information for designing of adsorbent bed to estimate the capacity of adsorption for the given period.

Experimental studies have also been performed to improve mass and heat transfer rates in adsorbent beds. Literature survey shows that the design of adsorbent bed can be classified according to the form of adsorbent.

\subsubsection{Uncoated type adsorber}

In this type of adsorbent bed, pellet, granule or fiber adsorbent is generally employed. Adsorbent is not treated and used as it is received from the manufacturer. However, there are some studies in which adsorbent is formed to a specific shape. The adsorbate moves in voids between pellet or granule and then adsorbed in the adsorbent. Based on porosity of the bed, convection and diffusion of adsorbate between pellets can be considered or removed in the heat and mass transfer equations. Fins can be employed in order to increase heat transfer rate in the bed; however, mass transfer rate through the bed is improved by creating voids in the bed. Some examples of uncoated type adsorbers are shown in Fig. 6. Fig. 6a depicts slim thin wall shell tube adsorber designed for improving

a

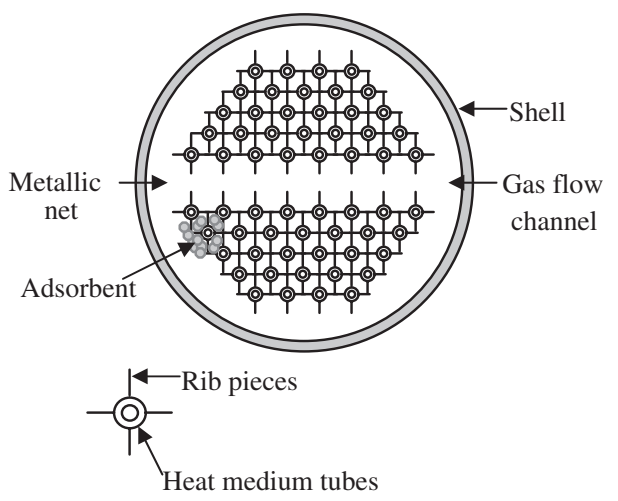

C

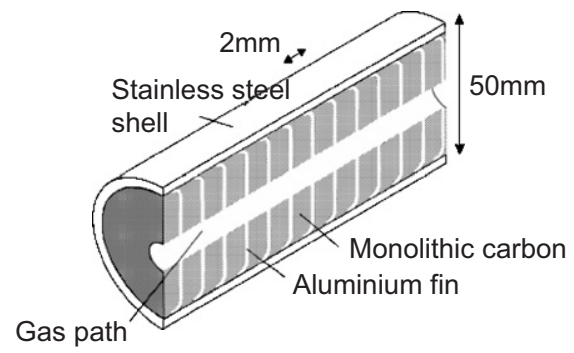

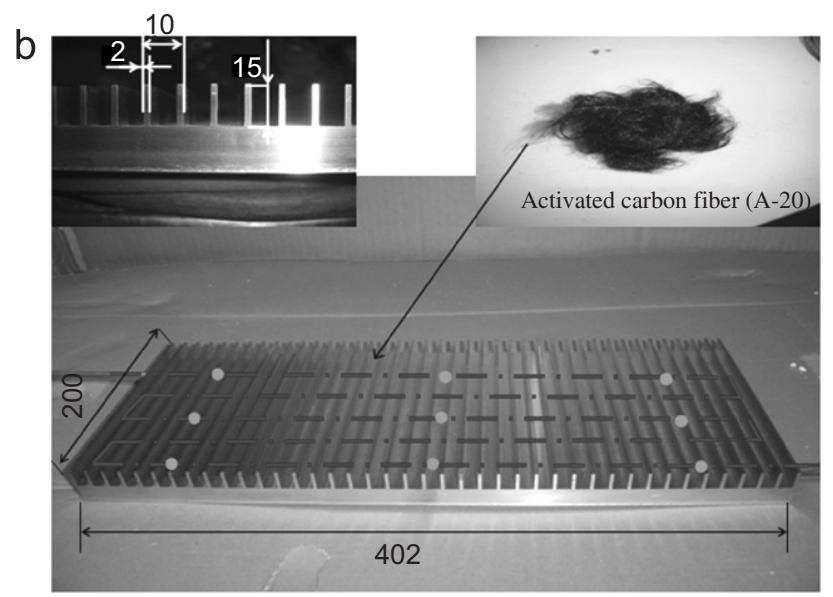

Fig. 6. Photograph of untreated type of adsorbent bed designs. 
heat transfer rate by Gui et al. [8]. The activated carbon used as adsorbent which is placed among the tubes that are used for heating and cooling. The rib pieces on tubes increase heat transfer rate from the tubes to the activated carbon, since the surface of heat transfer is increased. Saha et al. [35] employed activated carbon fiber as adsorbent. Activated carbon fibers have higher total pore volume, surface area and adsorption capacity than silica gel particles. Moreover, adsorption/desorption isotherm shows that activated carbon fibers do not have adsorption/desorption hysteresis. Activated carbon fibers are packed tightly inside oxygen-free copper fins as shown in Fig. 6b. Critoph et al. [73] developed prototype of a fast cycle adsorption refrigerator that is composed of laminate of monolithic carbon discs and aluminum fins as shown in Fig. 6c. The monolithic carbon is mixed with organic binder, compressed and fired.

\subsubsection{Coating type adsorber}

In this type of adsorber, adsorbent is coated around a pipe, fin or in metal foam. This type of adsorbent bed generates high speed heat and mass transfer. Diffusion in the adsorbent is accepted as the main mechanism of mass transfer since there is no void in the coated the adsorbents. Fig. 7a shows a coated stainless steel tube with adsorbent for improving heat and mass transfer rate in bed. This method allows obtaining high specific power adsorption heat pump [26]. Restuccia et al. [67] designed an adsorbent bed which is made of finned tubes covered with SWS-1L $\left(\mathrm{CaCl}_{2}\right.$ in mesoporous silica gel) adsorbent as shown in Fig. 7b. The optimal cycle time of system is $20-40 \mathrm{~min}$ and a cooling COP is varies between 0.17 and 0.48 . Bonaccorsi et al. [31] prepared open-cell copper foam as
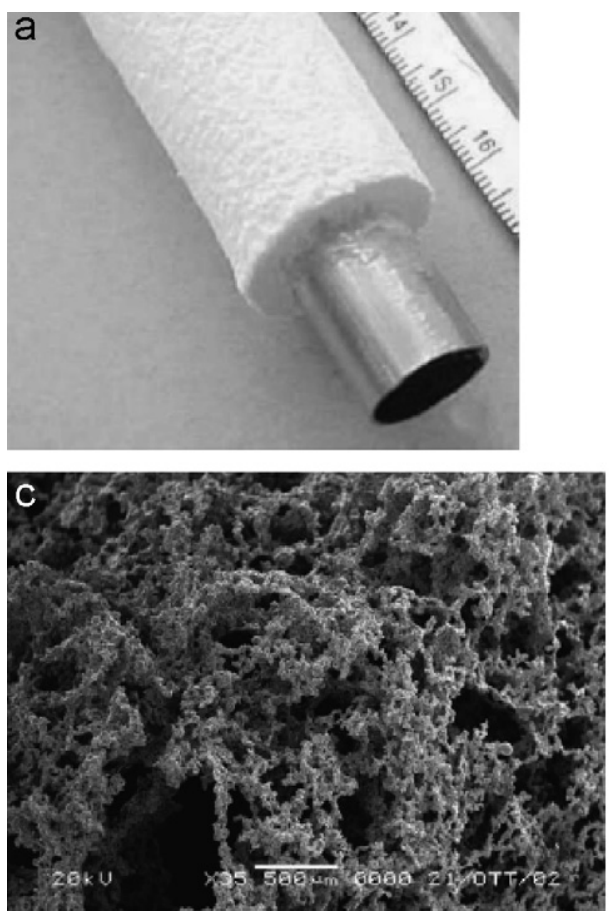
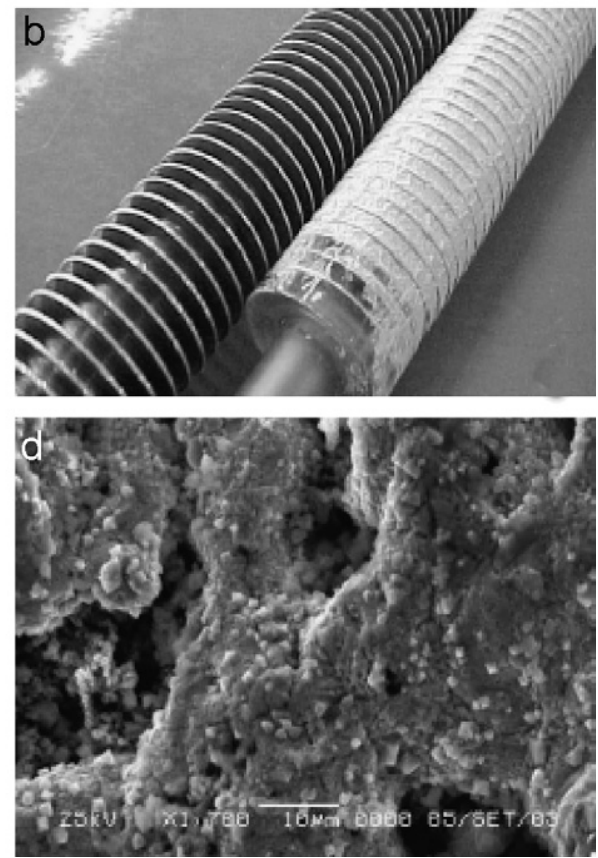

Fig. 7. Photograph of coated type of adsorbent bed designs. 
metal support for adsorbent bed as shown in Fig. 7c. The zeolite adsorbent is grown by hydrothermal synthesis on this metal support as shown in Fig. 7d.

\section{Conclusions}

Due to the ecological problems, mechanical heat pumps will face a serious crisis in the future if a solution is not found for working fluids by heat pump and refrigeration industry. Adsorption heat pumps are serious alternative for mechanical heat pumps since they do not contain any hazardous materials for environment. Researches have indicated that adsorption heat pump systems promise a potential for competing with the other conventional systems which are absorption and vapor compression heat pumps. One of the advantages of adsorption heat pumps is operation with thermal heat source and particularly waste heat. The COP of adsorption heat pumps is not high, compared to the other conventional heat pumps. They have other problems and difficulties during the design and production such as leakage, high vacuum, poor mass, and heat transfer. However, many researches are performed to develop innovative designs and cycles in order to eliminate those problems and enhance COP values. The researches are also focused on the solutions for the problem of leakage and high vacuum in adsorption heat pump systems since the cycle has to be repeated for many times under the same operation pressures. Novel designs for adsorbent bed are being searched to increase heat and mass transfer rates that directly influence the system effectiveness.

Difficulties of adsorption heat pumps are overcome one by one. Adsorption heat pump systems begin to find a narrow market in industry. There are companies commercially produce adsorption chillers and present these products to the market. Studies on application of adsorption heat pumps for utilization of solar energy as ice makers are increasingly continued. The recent developments in design and elimination of some problems of adsorption heat pump point out that the application of adsorption heat pumps will become widespread and popular in near future.

\section{References}

[1] Ülkü S. Adsorption heat pumps. Heat Recovery Syst 1986:277-84.

[2] Ülkü S. Solar adsorption heat pumps, solar energy utilization: fundamentals and applications. Yüncü H, Paykoç E, Yener Y, editors. The Netherlands: Martinus Nijkoff Publishers, 1987.

[3] Meunier F. Adsorptive cooling: a clean technology. Clean Prod Processes 2002;3:8-20.

[4] Wongsuwan W, Kumar S, Neveu P, Meunier F. A review of chemical heat pump technology and applications. Appl Therm Eng 2001;2:1489-519.

[5] Pons M, Kodama A. Entropic analysis of adsorption open cycles for air conditioning. Part 1: first and second law analyses. Int J Energy Res 2000;24:251-62.

[6] Kodama A, Jin W, Goto M, Hirose T, Pons M. Entropic analysis of adsorption open cycles for air conditioning. Part 2: interpretation of experimental data. Int J Energy Res 2000;24:263-78.

[7] Spinner B, Sorin M, Stitou D. Internal energy flow analysis within a single effect sorption heat pump. Int J Refrig 2001;24:185-91.

[8] Gui YB, Wang RZ, Wang W, Wu JY, Xu YX. Performance modeling and testing on a heat-regenerative adsorptive reversible heat pump. Appl Therm Eng 2002;22:309-20.

[9] Poyelle F, Guilleminot JJ, Meunier F. Experimental tests and predictive model of an adsorptive air conditioning unit. Ind Eng Chem Res 1999;38:298-309.

[10] Chahbani MH, Labidi J, Paris J. Effect of mass transfer kinetics on the performance of adsorptive heat pump system. Appl Therm Eng 2002;22:23-40. 
[11] Pons M, Meunier F, Cacciola G, Critoph RE, Groll M, Puigjaner L, et al. Thermodynamic based comparison of sorption systems for cooling and heat pumping. Int J Refrig 1999;22:5-17.

[12] Ülkü AS, Mobedi M. Adsorption in energy storage. Proc NATO Adv Stud Inst Energy Storage Syst Ser E Appl Sci 1989;167:487-507.

[13] Dous N, Meunier F. Experimental study of cascading adsorption cycles. Chem Eng Sci 1989;44:225-35.

[14] Szarzynski S, Feng Y, Pons M. Study of different internal vapour transports for adsorption cycles with heat regeneration. Int J Refrig 1997;20:390-401.

[15] Pons M, Szarzynski S. Accounting for the real properties of the heat transfer fluid in heat-regenerative adsorption cycles for refrigeration. Int J Refrig 2000;23:284-91.

[16] Chahbani MH, Labidi J, Paris J. Modeling of adsorption heat pumps with heat regeneration. Appl Therm Eng 2004;24:431-47.

[17] Saha BB, Akisawa A, Kashiwagi T. Silica gel water advanced adsorption refrigeration cycle. Energy 1997;22:437-47.

[18] Hamamoto Y, Amanul Alam KC, Akisawa A, Kashiwagi T. Performance evaluation of a two-stage adsorption refrigeration cycle with different mass ratio. Int J Refrig 2005;28:344-52.

[19] Saha BB, Koyama S, Choon Ng K, Hamamoto Y, Akisawa A, Kashiwagi T. Study on a dual-mode, multistage, multi-bed regenerative adsorption chiller. Renew Energy 2006;31:2076-90.

[20] Khan MZI, Alam KCA, Saha BB, Hamamoto Y, Akisawa A, Kashiwagi T. Parametric study of a two-stage adsorption chiller using re-heat the effect of overall thermal conductance and adsorbent mass on system performance. Int J Therm Sci 2005;45:511-9.

[21] Srivastava NC, Eames IW. A review of adsorbents and adsorbates in solid-vapour adsorption heat pump systems. Appl Therm Eng 1998;18:707-14.

[22] Wang SG, Wang RZ, Li XR. Research and development of consolidated adsorbent for adsorption systems. Renew Energy 2005;30:1425-41.

[23] Cerkvenik B, Poredos A, Ziegler F. Influence of adsorption cycle limitations on the system performance. Int J Refrig 2001;24:475-85.

[24] Wang S, Zhu D. A novel type of coupling cycle for adsorption heat pumps. Appl Therm Eng 2002;22:1083-6.

[25] Wang L, Zhu D, Tan Y. Heat transfer enhancement of the adsorber of an adsorption heat pump. Adsorption 1999;5:279-86.

[26] Restruccia G, Freni A, Maggio G. A zeolite-coated bed for air conditioning adsorption systems: parametric study of heat and mass transfer by dynamic simulation. Appl Therm Eng 2002;22:619-30.

[27] Hamamoto Y, Alam KCA, Saha BB, Koyama S, Akisawa A, Kashiwagi T. Study on adsorption refrigeration cycle utilizing activated carbon fibers. Part 1. Adsorption characteristics. Int J Refrig 2006; 29:305-14.

[28] Chua HT, Ng KC, Malek A, Kashiwagi T, Akisawa A, Saha BB. Multi-bed regenerative adsorption chillerimproving the utilization of waste heat and reducing the chilled water outlet temperature fluctuation. Int J Refrig 2001;24:124-36.

[29] Tather M, Erdem-Șenatalar A. Polymeric heat exchangers to increase the COP values of adsorption heat pumps utilizing zeolite coatings. Appl Therm Eng 2004;24:69-78.

[30] Meunier F. Second law analysis of a solid adsorption heat pump operating on reversible cascade cycles: application to the zeolite-water pair. J Heat Recovery Syst 1985;5:133-41.

[31] Bonaccorsi L, Freni A, Proverbio E, Restuccia G, Russo F. Zeolite coated copper foams for heat pumping applications. Microporous Mesoporous Mater 2006;91:7-14.

[32] Riffat SB, Williams MD, Corr S. Adsorption heat pump using HFC refrigerants. Int J Energy Res 1997;21:481-94.

[33] Bonaccorsi L, Proverbio E. Synthesis of thick zeolite 4A coatings on stainless steel. Microporous Mesoporous Mater 2004;74:221-9.

[34] Lambert MA. Design of solar powered adsorption heat pump with ice storage. Appl Therm Eng 2007;27:1612-28.

[35] Saha BB, Koyama S, El-Sharkawy II, Kuwahara K, Kariya K, Ng KC. Experiments for measuring adsorption characteristics of an activated carbon fiber/ethanol pair using a plate-fin heat exchanger. HVAC\&R Res 2006;12:767-82.

[36] Al-Ansari A, Ettouney H, El-Dessouky H. Water-zeolite adsorption heat pump combined with single effect evaporation desalination process. Renew Energy 2001;24:91-111.

[37] Tatler M, Erdem-Șenatalar A. Optimization of the cycle durations of adsorption heat pumps employing zeolite coatings synthesized on metal supports. Microporous Mesoporous Mater 2000;34:23-30. 
[38] Tather M, Erdem-Senatalar A. The effects of thermal and mass diffusivities on the performance of adsorption heat pumps employing zeolite synthesized on metal supports. Microporous Mesoporous Mater 1999;28:195-203.

[39] Tather M, Erdem-Șenatalar A. When do thin zeolite layers and a large void volume in the adsorber limit the performance of adsorption heat pumps? Microporous Mesoporous Mater 2002;54:89-96.

[40] Wu JY, Wang RZ, Xu YX. Influence of adsorption and desorption capacity on operating process for adsorption heat pump. Appl Therm Eng 2002;22:471-6.

[41] Sakoda A, Suzuki M. Fundamental study on solar powered adsorption cooling system. J Chem Eng Jpn 1984;17:52-7.

[42] Aittomäki A, Härkönen M. Zeolite heat pump - adsorption of methanol in synthetic zeolites 13X, A4 and 5A. Int J Refrig 1986;9:240-4.

[43] Critoph RE. Forced convection adsorption cycles. Appl Therm Eng 1998;18:799-807.

[44] Lemmini F, Meunier F. Simulation of an adsorptive solar refrigerator operating in Morocco. J Islamic Acad Sci 1990;3:273-9.

[45] Ramos M, Espinoza RL, Horn MJ. Evaluation of a zeolite-water solar adsorption refrigerator. ISES Solar World Congress, Göteborg, Sweden, June 14-19, 2003.

[46] Hennig H, Glaser H. Solar assisted adsorption system for a laboratory of the university Freiburg.

[47] Sumathy K. An energy efficient solar ice-maker. In: Proceedings of the 8th international symposium on renewable energy education (ISREE8), August 4-8, 2002.

[48] Dechang W, Jingyi W, Honggang S, Ruzhu W. Experimental study on the dynamic characteristics of adsorption heat pumps driven by intermittent heat source at heating mode. Appl Therm Eng 2005;25:927-40.

[49] Tather M, Erdem-Șenatalar A. The performance analysis of a solar adsorption heat pump utilizing zeolite coatings on metal supports. Chem Eng Commun 2000;180:169-85.

[50] Wu JY, Wang RZ, Xu YX. Dynamic analysis of heat recovery process for a continuous heat recovery adsorption heat pump. Energy Convers Manage 2002;43:2201-11.

[51] Tahat MA. Heat-pump/energy-store using silica gel and water as a working pair. Appl Energy 2001; 69:19-27.

[52] Tatlier M, Erdem-Şenatalar A. Effects of metal mass on the performance of adsorption heat pumps utilizing zeolite 4A coatings synthesized on heat exchanger tubes. Int J Refrig 2000;23:260-8.

[53] Oertel K, Sprengel U, Mande S, Ghosh P, Kishore VVN. Development of an advanced solar-hybrid adsorption cooling system for decentralized storage of agricultural products in India. DLR-TERI joint project report. The Commission of the European Communities, DG-XII, 1996.

[54] Henning HM, Wiemken E. Solar assisted air conditioning of buildings overview on technologies and state of the art. In: Proceedings of ISES Solar World Congress. Gothenburg, Sweden, 2003.

[55] Rothmeyer M, Laxhuber MP, Alefeld G. Design and performance of zeolite water heat pumps. In: Proceedings of the 16th international congress of refrigeration in Paris, 1983.

[56] Gross MD, Dawoud B. Experimental investigation of and adsorptive heat storage. In: Proceedings of the international sorption heat pump conference, Denver, USA, 2005.

[57] Metcalf JS. Simulation of the effect of generator heat transfer parameters on power density and efficiency in multiple-bed regenerative carbon-ammonia sorption heat pumps. In: Proceedings of the international sorption heat pump conference, Denver, USA, 2005.

[58] Nunez T, Mittelbach W, Henning MH. Development of a small capacity adsorption system for heating and cooling applications. In: Proceedings of the international sorption heat pump conference, Denver, USA, 2005.

[59] De Boer R, Smeding FS, Grisel HJR. Development and testing of a sorbent filled heat exchanger for use in compact solid sorption cooling systems. In: Proceedings of the international sorption heat pump conference, Denver, USA, 2005.

[60] Telto TZ. Compact sorption generator prototype. In: Proceedings of the international sorption heat pump conference, Denver, USA, 2005.

[61] Thorpe NR, Critoph ER, Zhong Y. Sorption of ammonia on calcium chloride/alumina calcium chloride/ active carbon composite materials. In: Proceedings of the international sorption heat pump conference, Denver, USA, 2005.

[62] Hamamoto Y, Akisawa A, Kashiwagi T. Study of a hybrid desiccant cooling system combined with a two-stage adsorption chiller. In: Proceedings of the international sorption heat pump conference, Denver, USA, 2005.

[63] Hauer A. Evaluation of adsorbent materials for heat pump and thermal energy storage applications in open systems. In: Proceedings of the international sorption heat pump conference, Denver, USA, 2005. 
[64] Wang CD, Wu YJ, Wang ZR, Xia ZZ. Research on a novel adsorption chiller driven by low grade heat source. In: Proceedings of the international sorption heat pump conference, Denver, USA, 2005.

[65] Wang ZR, Kong QX, Wu YJ, Huangfu Y, Wu WD. Performance research of a micro cchp system with adsorption chiller. In: Proceedings of the international sorption heat pump conference, Denver, USA, 2005.

[66] Elgowainy A, Shelton S, Hogan J. Experimental investigation of activated carbon-ammonia heat pump system. In: Proceedings of the international sorption heat pump conference, Denver, USA, 2005.

[67] Restuccia G, Vasta S, Freni A, Russo F, Aristov IY. An advanced solid sorption chiller using SWS-1L: performance analysis and hydrothermal cycling stability of the sorbent bed. In: Proceedings of the international sorption heat pump conference, Denver, USA, 2005.

[68] Wu J, Wang D, Zhai X, Wang R. Research on control method of the adsorption chiller driven by a variable heat source - solar energy. In: Proceedings of the international sorption heat pump conference, Denver, USA, 2005.

[69] Wang WL, Wang ZR, Lu SZ, Xu XY, Wu YJ. Split heat pipe type adsorption ice maker with compound adsorbent: a better choice for fishing boats. In: Proceedings of the international sorption heat pump conference, Denver, USA, 2005.

[70] Schnabel L, Henning MH. Experimental and simulation study on the kinetics of water vapour adsorption on different kinds of adsorptive material matrices. In: Proceedings of the international sorption heat pump conference, Denver, USA, 2005.

[71] Choi C, Jeong S. Experimental study on the development of micro adsorption refrigerator. In: Proceedings of the international sorption heat pump conference, Denver, USA, 2005.

[72] Dawoud B. A hybrid solar - assisted adsorption cooling unit for vaccine storage. In: Proceedings of the international sorption heat pump conference, Denver, USA, 2005.

[73] Critoph RE, Telto TZ, Davies LNG. A prototype of a fast cycle adsorption refrigerator utilizing a novel carbon-aluminium laminate. In: Proceedings of the institution of mechanical engineers, vol. 214, 2000. 